\title{
Properties of Concrete Mixes with Carwash Wastewater
}

\author{
Shahiron Shahidan ${ }^{\mathrm{a}}$, Mohamad Syamir Senin, Aeslina Binti Abdul Kadir, Lau Hai Yee, Noorwirdawati Ali \\ Department of Structural and Material Engineering,University Tun Hussein Onn Malaysia, Batu Pahat, 86400 Johor, Malaysia.
}

\begin{abstract}
The rapid growth of the car wash industry today results in the need for wastewater reclamation. Thus, this paper aims to investigate the effect of using car wash wastewater on concrete properties in terms of mechanical properties. The basic characteristics of wastewater were investigated according to USEPA (Method $150.1 \& 300.0$ ) while the mechanical properties of concrete with car wash wastewater were compared according to ASTM C1602 and BS EN 1008 standards. In this research, the compressive strength, modulus of elasticity and tensile strength were studied. The percentages of wastewater replaced in the concrete mix ranged from $0 \%$ up to $40 \%$. In addition, the results also suggest that the concrete with $20 \%$ car wash wastewater achieved the highest compressive strength and modulus of elasticity compared to other compositions of wastewater. Moreover, the results also recommended that concrete mixed with car wash wastewater has better compressive strength compared to conventional concrete.
\end{abstract}

\section{Introduction}

Malaysia is located in South East Asia with a population of approximately 31 million people. This nation receives an average annual rainfall of $3000 \mathrm{~mm}$. It means that there should not be any problems related to water shortage or scarcity [1-4]. Unfortunately, the water situation in Malaysia has changed from one of relative abundance to one of scarcity [5-6]. This is because of rapid population growth, urbanization, industrialization and the expansion of irrigated agriculture.

Generally, car wash stations are common in Malaysia. Therefore, car wash wastewater can be easily collected. Wastewater is normally generated by the process of washing private or public vehicles [3][4]. However, not much attention is being paid on reusing wastewater from the car wash industry. This may be due to the limited number of articles and journals emphasizing on the applications of reused car wash wastewater [5-13].

On the other hand, the lack of knowledge regarding the car wash wastewater management may be due to individual opinion. People may think that car wash wastewater is not as critically contaminated as other types of industrial wastewater [3]. Based on the evaluation of car wash effluent quality in Malaysia, the content of chemical oxygen demand (COD) in wastewater is above the tolerance limit specified by Malaysia standard A [3][11][14]. Table 1 shows the comparison between the typical characteristics of car wash effluent in Malaysia and the tolerance limit set by Malaysia standard A. According to the latest statistics of the car industry in Malaysia, the total vehicle sales in 2015 between January to September is 485,388 units and is predicted to hit

\footnotetext{
a Corresponding author: shahironshahidan@gmail.com
}

another new record of a total of 670,000 units at the end of 2015 compared to 655,793 units and 666,465 units in 2013 and 2014 respectively [15-19]. The growth of land transports together with the current number of cars would definitely lead to increasing demand for car wash services especially in highly populated housing areas located in towns [3].

Besides that, car wash stations which consume larger capacities of fresh water on a daily basis could benefit from recycling programs [8]. According to Karakulski \& Morawski (2003) and Panizza\&Cerisola (2010), an average of 150 to 600 litres of car wash wastewater is produced from every car wash. Consequently, it is estimated that 2.5 million gallons of fresh water are consumed daily at car wash stations [7].

Apart from that, car wash wastewater can be harmful to humans and the environment if released untreated to surface water-bodies because it may contain many pollutants such as detergents that can be poisonous to fish, oil, grease, sand, dust, chemicals and solventbased solutions, heavy metals and organic matter [8][13][14][20].Subsequently, the Environmental Pollution Agency raised public awareness on the impurities found in car wash wastewater such as heavy metals, polycyclic aromatic hydrocarbons (PAH) and volatile organic compounds (VOC) [17][20-23]. Considering the gigantic amounts of effluent generated and its complex characteristics, reusing car wash wastewater is not only a process to manage environmental problems but is also a way to recover a significant amount of wastewater directly discharged into rivers and oceans [24-29]. Therefore, reusing car wash wastewater in concrete mixes aims to create a sustainable 
solution in this industry towards green technology in construction.

Al-Jabri, et al (2011) from Oman used car wash wastewater to manufacture concrete. Wastewater characteristics including $\mathrm{pH}$ value, chloride, alkalinity and sulphate content in wastewater were determined. The results indicated that the characteristics of wastewater were within the ASTM standard limits. The mechanical test of concrete included compressive strength, tensile strength and a flexural test on day 28 [30-32]. In addition, the percentages of car wash wastewater in the concrete mix ranged from $25 \%$ to $100 \%$ [33]. The experimental results suggested that the strength of concrete containing car wash wastewater was comparable with the control mix [29]. Therefore, this research will mainly focus on characterization of car wash wastewater and the effect of wastewater on concrete properties. The presence of chloride and sulphate in car wash wastewater were analysed and compared with the ASTM standards [33]. The tests for concrete properties which included compressive strength, tensile strength and modulus of elasticity were performed according to the ASTM standards [34-37].

\section{Materials and Experimental Work}

In this research, the replacement percentages of car wash wastewater in concrete mixes were at $10 \%, 20 \%, 30 \%$, and $40 \%$ of tap water. The water cement ratio w/c is 0.45 and all the concrete specimens were designed to have a target mean strength of $35 \mathrm{MPa}$ according to the DOE method [30]. 30 concrete specimens measured $150 \times 150$

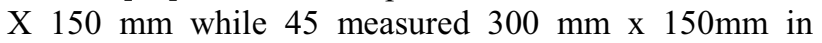
diameter. The tests related to this research are compressive strength, tensile strength and modulus of elasticity (MOE).

\subsection{Materials}

\subsubsection{Water}

Car wash wastewater was collected from two different car wash stations in Batu Pahat, Johor, Malaysia which are MAHAJU (MJ) car wash enterprise and Bandar U car wash station. Before the wastewater was collected, the washout water from vehicles was discharged into a pond through a drainage system. The chemical properties of car wash wastewater were analysed according to USEPA standard method and compared with the standard specifications [22][38-40].

\subsubsection{Cement}

A local Ordinary Portland cement type CEM $142.5 \mathrm{~N}$ was used in this research and it complied with the requirements of MS EN 197-1[32]. The physical and chemical properties of cement shown in Table 1 and Table 2 respectively.
Table 1. Physical properties of cement

\begin{tabular}{|l|c|}
\hline \multicolumn{1}{|c|}{ Property } & OPC \\
\hline Specific gravity & 3.15 \\
\hline Passing grain size & $78 \%$ \\
\hline Median grain size & $18 \mu \mathrm{m}$ \\
\hline Blaine specific surface & $300 \mathrm{~m}^{2} / \mathrm{kg}$ \\
\hline Initial setting time & $145 \mathrm{Min}$ \\
\hline Final setting time & $270 \mathrm{Min}$ \\
\hline
\end{tabular}

Table 2. Chemical properties of cement

\begin{tabular}{|l|c|}
\hline \multicolumn{1}{|c|}{ Component } & \% \\
\hline Silicon dioxide, $\mathrm{SiO}_{2}$ & 21.2 \\
\hline Aluminium oxide, $\mathrm{Al}_{2} \mathrm{O}_{3}$ & 5.5 \\
\hline Iron oxide, $\mathrm{Fe}_{2} \mathrm{O}_{3}$ & 3.1 \\
\hline Calcium oxide, $\mathrm{CaO}$ & 63.7 \\
\hline Magnesium oxide, $\mathrm{MgO}$ & 1.5 \\
\hline Sodium oxide, $\mathrm{Na}_{2} \mathrm{O}$ & 0.18 \\
\hline Potassium oxide, $\mathrm{K}_{2} \mathrm{O}$ & 0.71 \\
\hline Sulfur trioxide, $\mathrm{SO}_{3}$ & 2.63 \\
\hline Loss on ignition & 0.96 \\
\hline
\end{tabular}

\subsubsection{Aggregates}

Fine and coarse aggregates according to the ASTM C33 requirements [33], ASTM C33 and BS 882 standards were used to control the aggregates sizes using a sieve analysis [34-36].

\subsection{Mix Proportion of Concrete}

All concrete specimens were designed to have a target mean strength of $35 \mathrm{MPa}$ according to the Department of Environment (DOE) method [30]. Table 3 shows the mix proportions of concrete.

Table 3. Mix proportion of concrete

\begin{tabular}{|c|c|c|c|c|c|}
\hline $\begin{array}{c}\text { Mix } \\
\mathbf{\%}\end{array}$ & $\begin{array}{c}\text { Cement } \\
\left(\mathbf{k g} / \mathbf{m}^{\mathbf{3}}\right)\end{array}$ & $\begin{array}{c}\text { Tap } \\
\mathbf{W a t e r} \\
\left(\mathbf{k g} / \mathbf{m}^{\mathbf{3}}\right)\end{array}$ & $\begin{array}{c}\mathbf{C W} \\
\left(\mathbf{k g} / \mathbf{m}^{\mathbf{3}}\right)\end{array}$ & $\begin{array}{c}\mathbf{F . A} \\
\left(\mathbf{k g} / \mathbf{m}^{\mathbf{3}}\right)\end{array}$ & $\begin{array}{c}\mathbf{C . A} \\
\left(\mathbf{k g} / \mathbf{m}^{\mathbf{3}}\right)\end{array}$ \\
\hline CM 0 & 414 & 180 & 0 & 535 & 1245 \\
\hline CW10 & 414 & 162 & 18 & 535 & 1245 \\
\hline CW20 & 414 & 144 & 36 & 535 & 1245 \\
\hline CW30 & 414 & 126 & 54 & 535 & 1245 \\
\hline CW40 & 414 & 108 & 72 & 535 & 1245 \\
\hline
\end{tabular}

*F.A (Fine Aggregate); C.A (Coarse Aggregate); CW (Car Wash Wastewater) 


\subsection{Experimental Work}

\subsubsection{Wastewater Analysis}

The car wash wastewater $\mathrm{pH}$ value was measured using Hanna HI 8424 digital pH meter. The sulphate and chloride content in car wash wastewater were analysed according to the United States Environmental Protection Agency USEPA method 300.0.

\subsubsection{Concrete Testing}

The manufacturing and curing process of concrete were according to ASTM standards. The concrete slump tests were performed according to ASTM C 143.The compressive strength and tensile strength of concrete were evaluated in accordance with ASTM C39 and ASTM C496 respectively and modulus of elasticity (MOE) of concrete was tested according to ASTM C469[31-36].

\section{Result and Discussion}

\subsection{Car Wash Wastewater Characterization}

Table 4 and Table 5 show the results of car wash wastewater characterization and tolerance limit of water mixed in concrete respectively.

Table 4. Wastewater characteristics

\begin{tabular}{|c|c|c|c|}
\hline \multirow{2}{*}{$\begin{array}{c}\text { Parameters/ } \\
\text { Sources }\end{array}$} & \multicolumn{3}{|c|}{ Parameters } \\
\hline & pH & $\begin{array}{c}\text { Chloride } \mathrm{Cl}^{-} \\
\text {, ppm }\end{array}$ & $\begin{array}{c}\text { Sulphate } \\
\mathrm{SO}_{4}{ }^{2-}, \mathrm{ppm}\end{array}$ \\
\hline \multicolumn{4}{|c|}{ Car Wash Wastewater } \\
\hline $\begin{array}{l}\text { MAHAJU } \\
\text { Car Wash } \\
\text { Station }\end{array}$ & $8.8-9.5$ & $19.4-33.0$ & $\begin{array}{l}12.6- \\
115.5\end{array}$ \\
\hline $\begin{array}{c}\text { Bandar U } \\
\text { Car Wash } \\
\text { Station }\end{array}$ & $9.5-10.6$ & $18.2-25.4$ & $\begin{array}{l}16.1- \\
100.4\end{array}$ \\
\hline \multicolumn{4}{|c|}{ Tap Water } \\
\hline Tap Water & $7.6-8.1$ & $19.4-19.7$ & $13.3-13.4$ \\
\hline
\end{tabular}

Table 5. Tolerance limit of wastewater in concrete

\begin{tabular}{|c|c|c|c|}
\hline \multirow{2}{*}{ Standards } & \multicolumn{3}{|c|}{ Tolerance limit, ppm } \\
\cline { 2 - 4 } & $\begin{array}{c}\text { Chloride } \\
\text { CI, } \mathbf{p p m}\end{array}$ & $\begin{array}{c}\text { Sulphate } \\
\text { SO }_{4}^{2-}, \mathbf{p p m}\end{array}$ & pH \\
\hline ASTM C1602 & $<500$ & $<3000$ & - \\
\hline ASTM C685 & $<500$ & $<3000$ & - \\
\hline BS EN 1008 & $<500$ & $<2000$ & $>4$ \\
\hline BS 3148 & $<500$ & $<1000$ & - \\
\hline \multicolumn{4}{|c|}{ Previous Researchers } \\
\hline$[3][6][7][8][1$ & $9-74.2$ & $21.3-188.0$ & $6.5-8.75$ \\
$4][15][19][31]$ & & \\
\hline
\end{tabular}

Referring to Table 4 and Table 5, the car wash wastewater characteristics were completely in line with the standards as well as the typical values suggested by previous researchers except the $\mathrm{pH}$ value for car wash wastewater. Even though this research obtained higher $\mathrm{pH}$ values compared to previous studies, the range of $\mathrm{pH}$ value is still in the range of typical car wash wastewater according to the Standard A-1978 which varies from 6.0 to 9.0. In addition, the higher $\mathrm{pH}$ value in car wash wastewater may be due to chemicals used in pre-soak stages during the car wash process as supported by previous studies by Zaneti et al., (2011) [37]. Furthermore, BS EN 1008, (2002) mentioned that the typical $\mathrm{pH}$ value of water for mixing concrete should be at least higher than four $(>4)$. Therefore, car wash wastewater can potentially be used in concrete mixes due to its reasonable characteristics.

\subsection{Properties of Fresh Concrete}

\subsubsection{Slump Test}

In this study, the concrete slump test was conducted according to ASTM C143 and the results were listed in Table 6.

Table 6. Slump Test

\begin{tabular}{|c|c|}
\hline Wastewater Type & $\begin{array}{c}\text { Slump Value } \\
\text { (mm) }\end{array}$ \\
\hline Control Mix, CM & 32 \\
\hline Car Wash Wastewater, CW 10\% & 42 \\
\hline Car Wash Wastewater, CW 20\% & 38 \\
\hline Car Wash Wastewater, CW 30\% & 43 \\
\hline Car Wash Wastewater, CW 40\% & 45 \\
\hline
\end{tabular}

As presented in Table 6, the slump values for car wash wastewater were comparable to the control mix. As mentioned in sub topic 2 , the target mean slump value varied from $30 \mathrm{~mm}$ to $60 \mathrm{~mm}$. This proved that the slump values of concrete with car wash wastewater were in the designated range. In addition, the results revealed that the slump value corresponds with the percentage of car wash wastewater in concrete.

\subsection{Mechanical Properties of Concrete}

\subsubsection{Compressive Strength}

Table 7 show the comparison between car wash wastewater mix and control mix in terms of compressive strength. 
Table 7. Compressive strength of car wash waste water mix

\begin{tabular}{|c|c|c|c|}
\hline $\begin{array}{c}\text { Concrete } \\
\text { Type }\end{array}$ & $\begin{array}{c}\text { Strength } \\
\text { on 7 Days } \\
\text { (MPa) }\end{array}$ & $\begin{array}{c}\text { Strength } \\
\text { on 28 Days } \\
\text { (MPa) }\end{array}$ & $\begin{array}{c}\text { ASTM C1602 } \\
\text { Minimum } \\
\text { Wastewater } \\
\text { Concrete At 7 } \\
\text { days (>90\%) } \\
\text { of Control } \\
\text { Strength }\end{array}$ \\
\hline CM & 44.14 & 50.01 & $100.00 \%$ \\
\hline CW 10\% & 39.14 & 47.98 & $88.67 \%$ \\
\hline CW 20\% & 44.74 & 52.70 & $101.36 \%$ \\
\hline CW 30\% & 46.11 & 51.17 & $104.46 \%$ \\
\hline CW 40\% & 41.73 & 49.19 & $94.54 \%$ \\
\hline
\end{tabular}

According to Table 7, the compressive strength of car wash wastewater concrete was in the range of $88 \%$ to $104 \%$ of normal concrete. This range was beyond the minimum limit of $90 \%$ specified in ASTM C1602 except for $10 \%$ car wash wastewater replacement. However, at 28 days all the specimens of concrete mix with car wash wastewater were not only above the limits of the standard, but also indicated a slight improvement especially for concrete with $20 \%$ and $30 \%$ car wash wastewater. This may be due to the fine solid particles present in the car wash wastewater which filled the pores or voids between fine aggregates and coarse aggregates. This may improve the strength of concrete but it would depend on suitable replacement percentages of car wash wastewater in concrete mixes [31][41-42].

In addition, the presence of chloride in car wash wastewater should be taken into account because the concentration of chloride in car wash wastewater is higher than normal concrete. This concentration may lead to corrosion on the steel reinforcement which could damage the bonding between rebars and concrete [40-45].

\subsubsection{Tensile Strength}

Table 8 and Figure 1 demonstrated the comparison of tensile strength between car wash wastewater mix and control mix.

Table 8. Tensile strength of car wash wastewater mix

\begin{tabular}{|c|c|c|}
\hline Concrete Type & $\begin{array}{c}\text { 7 Days Strength } \\
\text { (MPa) }\end{array}$ & $\begin{array}{c}\text { 28 Days } \\
\text { Strength } \\
\text { (MPa) }\end{array}$ \\
\hline CM & 2.74 & 2.90 \\
\hline CW 10\% & 2.16 & 2.96 \\
\hline CW 20\% & 2.30 & 3.13 \\
\hline CW 30\% & 2.83 & 3.17 \\
\hline CW 40\% & 2.77 & 3.00 \\
\hline
\end{tabular}

Referring to Table 8, all the results of the tensile strength of car wash wastewater were above the mean tensile strength value specified by BS EN 1992 [34]. The range of tensile strength was between $2.96 \mathrm{MPa}$ to 3.17 $\mathrm{MPa}$ compared to the standard value of $2.8 \mathrm{MPa}$. These results concluded that the replacement of car wash wastewater in concrete mixes met the specifications from BS EN 1992. The presence of fine particles in wastewater may have also filled the voids and pores in concrete and improved the interconnection between concrete materials [19].

On the other hand, the existence of chloride concentration in car wash wastewater could affect the tensile strength of concrete [19][36]. Based on the data in Table 2, the concentration of chloride in car wash wastewater is slightly higher than tap with a range between $19.4 \mathrm{ppm}$ to $33.0 \mathrm{ppm}$ compared to tap water which contains chloride concentration ranging from 19.4 ppm to $19.7 \mathrm{ppm}$. Therefore, the correlation between car wash wastewater and other concrete materials need to be further studied. This is because the presence of chloride content in wastewater may reduce the tensile strength of concrete [37][38][39].

\subsubsection{Modulus of Elasticity (MOE)}

Figure 1 demonstrated the procedure of modulus of elasticity (MOE) testing. However, Table 9 present the comparison of modulus of elasticity between car wash wastewater mix and control mix.

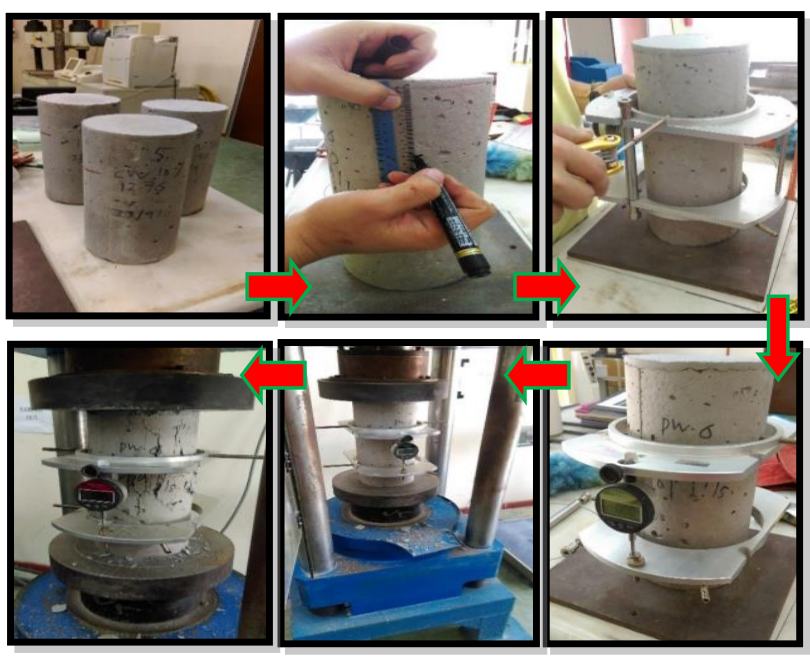

Figure 1. Procedure of modulus of elasticity testing

Table 9. Modulus of elasticity of car wash wastewater mix

\begin{tabular}{|c|c|}
\hline Concrete Type & 28 Days MOE (GPa) \\
\hline CM $0 \%$ & 29.38 \\
\hline CW $10 \%$ & 32.96 \\
\hline CW $20 \%$ & 33.62 \\
\hline CW $30 \%$ & 28.73 \\
\hline CW $40 \%$ & 28.62 \\
\hline
\end{tabular}

As mentioned in BS EN 1992, the typical range of secant modulus of elasticity of concrete $(\mathrm{Ecm})$ grade 35 was $32 \pm 6 \mathrm{GPa}$ [34]. So, the results in Table 9 completely achieved the typical range of MOE for concrete with a mean strength of $35 \mathrm{MPa}$. According to the information in Table 8 , the concrete with $20 \%$ of car wash wastewater replacement demonstrated the highest MOE value compared to other percentages as well as 
control mix with only $29.4 \mathrm{GPa}$. These findings may correlate to the existence of fine solid particles in wastewater which could fill the pores and voids in between the fine and coarse aggregates in concrete structures. According to previous researchers, the factors affecting the MOE were concrete strength and concrete density [42-45]. The concrete strength effect was related to the concrete compressive strength while the concrete density was related to the porosity of concrete. Based on the results in Table 8 , the sulphate content in car wash wastewater was between $12.6 \mathrm{ppm}$ to $115.5 \mathrm{ppm}$ compared to tap water which had a sulphate content of $13.3 \mathrm{ppm}$ to $13.4 \mathrm{ppm}$. Previous researchers revealed that a higher sulphate concentration may result secondary gypsum is formed with calcium hydroxide and developing crystallise causing expansion. Thus it is recommended to use sulphate resistant cement to make sure the concrete impermeable as possible.

\section{Conclusions}

Based on the results from the experimental work the following conclusions for the use of car wash wastewater in concrete mixes can be drawn:

- The $\mathrm{pH}$ value for car wash wastewater was in the range of 8.8 to 10.6 which is slightly higher than tap water. However, the sulphate and chloride content in car wash wastewater were within the ASTM and BS standards requirement.

- The used of $10 \%$ car wash wastewater result the lowers value of compressive strength, tensile strength and modulus of elasticity, however it show increasing while $20 \%$ and $30 \%$ but beyond the $30 \%$ all the result decreasing.

- The results recommended that a higher compressive strength value may lead to a higher MOE value.

- According to the results for compressive strength and modulus of elasticity, the optimum percentage of car wash wastewater as a fresh water replacement in concrete mixes is $20 \%$.

\section{Acknowledgement}

The authors would like to thank UTHM fellowship, VOT U523 and Grant GPPS U572. This paper was partly sponsored by the Centre for Graduate Studies, UTHM.

\section{References}

1. M. Y. Chong, "Malaysia Faces Looming Water Crisis: Sustainable Water Management," The Star Newspaper, Malaysia, (2011).

2. Z. B. Zaharaton, "Water Resources Management in Malaysia - The Way Forward," Asian Water, Kuala Lumpur, Malaysia, (2004).

3. S. Shahidan, I. Isham, and N. Jamaluddin, "A Review on Waste Minimization by Adopting in Self Compacting Concrete," MATEC Web Conf., vol. 47, pp. 1-7, 2016.
4. W. J. Lau, A. F. Ismail and S. Firdaus, "Treatment of car wash effluent using ultrafiltration and nanofiltration membranes," Separation and Purification Technology, vol. 104, pp. 26-31, (2013).

5. M. A. Wahid and H. Tanaka, "Potential Implementation of Wastewater Reclamation and Reuse in Malaysian Urban Area," International Sustainability and Civil Engineering Journal, vol. 1, no. 1, pp. 75-83, (2012).

6. K. Boussu, G. Van Baelan, W. Colen, D. Eelen, S. Vanassche, C. Vandecasteele and B. Van der Bruggen, "Technical and economical evaluation of water recycling in the carwash industry with membrane processes," Water Science and Technology, vol. 57, no. 7, pp. 1131-1135, (2008).

7. K. Boussu, C. Kindts, C. Vandecasteele and B. Van der Bruggen, "Applicability of nanofiltration in the carwash industry," Seperation Purification Technology, vol. 54, pp. 139-146, (2007).

8. A. Al-Odwani, A. Ahmed and S. Bou-Hamad, "Carwash water reclamation in Kuwait," Desalination, vol. 206, pp. 17-28, (2007).

9. N. Md Nor, N. Muhamad Bunnori, A. Ibrahim, S. Shahidan, and S. N. M. Saliah, "An investigation on acoustic wave velocity of reinforced concrete beam in-plane source," in Proceedings - 2011 IEEE 7th International Colloquium on Signal Processing and Its Applications, CSPA 2011, 2011, pp. 19-22.

10. T. Hamada and Y. Miyazaki, "Reuse of carwash water with a cellulose acetate ultrafiltration membrane aided by flocculation and activated carbon treatments," Journal of Desalination. Volume, vol. 169, pp. 257-267, (2004).

11. K. Karakulski and A. W. Morawski, "Treatment of wastewater from wastewater from car washes by ultrafiltration," Fresenius Environment Bulletin, vol. 12, pp. 343-348, (2003).

12. C. Jonsson and A. S. Jonsson, "The influence of degreasing agents used at car washes on the performance of ultrafiltration membranes," Desalination, vol. 100, pp. 115-123, (1995).

13. Malaysia Standard A, Environmental Quality Regulations: Sewage and Industrial Effluents, cyberjaya, Selangor: Government of Malaysia, (1978).

14. S. Shahidan, R. Pullin, K. M. Holford, M. B. N, and N. Nor, "Quantitative Evaluation of the Relationship between Tensile Crack and Shear Movement in Concrete beams," Adv. Mater. Res., vol. 626, pp. 355-359, 2013.

15. M. Panniza and G. Cerisola, "Applicability of electrochemical methods to carwash wastewaters for reuse. Part 1: Anodic oxidation with diamond and lead dioxide anodes," Journal of Electronic and Chemical, vol. 638, pp. 28-32, (2010).

16. E. Bazrafshan, F. K. Mostafapoor, M. M. Soori and A. H. Mahvi, "Application of Combined Chemical Coagulation and Electro-Coagulation Process for Carwash Wastewater Treatment," Environmental Bulletin, vol. 21, no. 9, pp. 2694-2701, (2012).

17. M. Abdul Rahim, N. M. Ibrahim, Z. Idris, Z. M. Ghazaly, S. Shahidan, N. L. Rahim, L. A. Sofri, and 
N. F. Isa, "Properties of Concrete with Different Percentange of the Rice Husk Ash (RHA) as Partial Cement Replacement," Mater. Sci. Forum, vol. 803, pp. 288-293, 2014.

18. S. Shahidan, N. M. Bunnori, N. Md Nor, and S. R. Basri, "Damage severity evaluation on reinforced concrete beam by means of acoustic emission signal and intensity analysis," in 2011 IEEE Symposium on Industrial Electronics and Applications, 2011, pp. 337-341.

19. Z. A. Bhatti, Q. Mahmood, I. A. Raja, A. H. Malik and $\mathrm{D}$. $\mathrm{Wu}$, "Chemical Oxidation of Carwash Industry Wastewater as an Effort to Decrease Water Pollution," Journal of Physics and Chemistry of the Earth, vol. 36, pp. 465-469, (2011).

20. B. O. Kwach and J. O. Lalah, "High Concentration of Polycyclic aromatic Hydrocarbons found in Water and Sediments of Car Wash and Kisat areas of Winam Gulf, Lake Vctoria Kenya," Bulletin of Environmental Contamination and Toxicology, vol. 83, no. 5, pp. 727-733, (2009).

21. Z. Nadzirah, N. H. Haslina and H. Rafidah, "Removal of Important Parameter from Car Wash Wastewater," Applied Mechanics and Materials, vol. 773, pp. 1153-1157, (2015).

22. USEPA, "EPA's Polluted brochure," United States Environmental Protection Agency, United States, (1994).

23. K. S. Al-Jabri, A. H. Al-Saidy, R. Taha and A. J. AlKemyani, "Effect of using Wastewater on the Properties of High Strength Concrete," Procedia Engineering, vol. 14, pp. 370-376, (2011).

24. ASTM C1602, Specification for Mixing Water Used in the Production of Hydraulic Cement Concrete, Pennsylvania, United States: American Society for Testing and Materials, (2006).

25. ASTM C39, Test Method for Compressive Strength of Cylindrical Concrete Specimens, Pennsylvania, United States: American Society for Testing and Materials, (2005).

26. ASTM C496, Test Method for Splitting Tensile Strength of Cylindrical Concrete Specimens, Pennsylvania, United States: American Society for Testing and Materials, (2004).

27. ASTM C469, Test Method for Static Modulus of Elasticity and Poisson Ratio of Concrete in Compression, Pennsylvania, United States: American Society for Testing and Materials, (2002).

28. S. A. Kudus, N. M. Bunnori, S. R. Basri, S. Shahidan, M. N. M. Jamil, and N. M. Noor, "An Overview Current Application of Artificial Neural Network in Concrete," Adv. Mater. Res., vol. 626, pp. 372-375, 2012.

29. S. Shahidan, H. B. Koh, A. M. S. Alansi, and L. Y. Loon, "Strength Development and Water Permeability of Engineered Biomass Aggregate Pervious Concrete," MATEC Web Conf., vol. 47, pp. 2-7, 2016

30. DOE 1988, Design of Normal Concrete Mixes. Building Research Establishment, Watford, United Kingdom: Department of the Environmental, (1988).
31. BS EN 1008, Mixing Water for ConcreteSpecification for Sampling, Testing and Assessing the Suitability of Water, Including Water Recovered from Processes in the Concrete Industry, as Mixing Water in Concrete, London: British Standards Institution, (2002).

32. MS EN 197-1, Composition, specifications and conformity criteria for common cements, Cyberjaya, Selangor: Department of Standards Malaysia , (2014).

33. ASTM C33, Specification for Concrete aggregates, Pennsylvania, United States: American Society for Testing and Materials, (2003).

34. BS 882, Specification for Aggregates from Natural Sources for Concrete, London: British Standards Institution, (1992).

35. ASTM C192, Practice for Making and Curing Concrete Test Specimens in the Laboratory, Pennsylvania, United States: American Society for Testing and Materials, (2006).

36. ASTM C143, Test Method for Slump of Hydraulic Cement Concrete, Pennsylvania, United States: American Society for Testing and Materials, (2005).

37. R. Zaneti, R. Etchepare and J. Rubio, "Car wash wastewater reclamation. Full- scale application and upcoming features," Resources, Conservation and Recycling, vol. 55, no. 11, pp. 953-959, (2011).

38. A. M. Neville, Properties of Concrete, 4th ed., London: Pearson, (1995).

39. L. Tang, N. Lars-Olof and B. P. Muhammed, Resistance of Concrete to Chloride Ingress, London: Spom Press, (2012).

40. C. Martin, "nfluence of Supplementary Cementitious Materials (SCMs) on concrete durability," Ecoefficient concrete, pp. 153-197, (2013).

41. BS EN 1992, Design of Concrete Structure, London: British Standards Institution, (2004).

42. O. S. Lee, M. R. Salim, M. Ismail and M. I. Ali, "Reusing treated effluent in concrete technology," Jurnal Teknologi, vol. 34, pp. 1-10, (2001).

43. G. Murali, C. M. Vardhan, S. Raju, C. Mahalakshmi, G. Srinidhi and D. S. Zachariag, "Influence of various industrial effluents on concrete structures," International Journal of Engineering Research and Application (IJERA), vol. 2, no. 2, pp. 704-709, (2012).

44. Z. Z. Ismail and E. A. Al-Hashmi, "Assessing the recycling potential of industrial wastewater to replace fresh water in concrete mixes: application of polyvinyl acetate resin wastewater," Journal of Cleaner Production, vol. 19, no. 2-3, pp. 197-203, (2011).

45. A. H. Noruzman, B. Muhammad, M. Ismail and A. Z. Majid, "Characteristics of treated effluents and their potential applications for producing concrete," Journal of Environmental Management, vol. 110, pp. 27-32, (2012). 